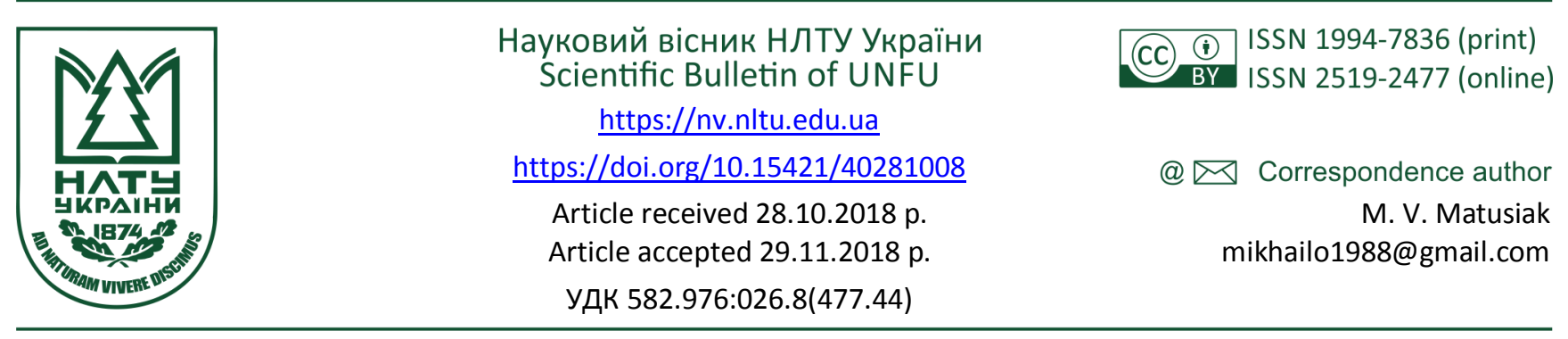

M. В. Матусяк

Вінницький національний аграрний університет, м. Вінниця, Украйна

\title{
БІОЛОГО-ЕКОЛОГІЧНІ ОСОБЛИВОСТІ ВИКОРИСТАННЯ ВИДІВ РОДУ ЖИМОЛОСТЬ (LONICERA L.) В УМОВАХ БІОСТАЦІОНАРУ ВІННИЦЬКОГО НАЦІОНАЛЬНОГО АГРАРНОГО УНІВЕРСИТЕТУ
}

\begin{abstract}
Аналіз результатів фенологічних спостережень здійснено за 7 фазами, які відображають основні моменти сезонного розвитку рослин. Для порівняння ритму розвитку інтродуцентів у нових умовах взято жимолость звичайну, як найбільш пристосовану до наших умов. Встановлено, що в наших умовах початок вегетації жимолостей розпочинається наприкінці березня - на початку квітня, коли середньодобова температура не перейшла через позначку $+6^{\circ} \mathrm{C}$. Більшість досліджуваних видів починають вегетацію до 4.04, коли за середньо багаторічними даними починається період вегетації у більшості рослин. Пізніше цього терміну розпочинає вегетацію жимолость звичайна. Визначено, що початок росту пагонів у досліджуваних видів спостерігається у другій-третій декаді квітня. Цьому відповідає середня температура повітря $6,8-10,5^{\circ} \mathrm{C}$, за суми активних температур вище нуля $205-227^{\circ} \mathrm{C}$. Фактичну зимостійкість встановлено за 5-бальною шкалою обмерзання М. К. Вєхова. Внаслідок проведених спостережень виявлено пошкодження $40 \%$ верхівок однорічних пагонів жимолості каприфоль (до 15-30 см), що однак не стало причиною втрати декоративності, оскільки цей вид має сильний приріст (60-120 см), тож немає підстави стверджувати про цілковиту незимостійкість та незначну перспективність цього виду. Жимолость звичайна обмерзання не мала. Завдяки нормальному розвитку пагонів, види утворюють добре сформовану крону, що $є$ для них характерним. Аналізуючи отримані результати, зроблено висновок, що найвища фактична зимостійкість в умовах м. Вінниці $\epsilon$ вид жимолость звичайна. Внаслідок вивчення життєздатності та перспективності досліджуваних видів жимолості встановлено, що цілком перспективними в умовах біостаціонару ВНАУ виявились жимолость звичайна (бал перспективності - I), а жимолость каприфоль належить до групи перспективних видів (бал перспективності - II), що дає змогу широко використовувати ці види в озелененні міста.
\end{abstract}

Ключові слова: біостаціонар; Жимолостеві; адаптація; інтродукція; акліматизація; зимостійкість.

Вступ. Вивчення особливостей застосування в озелененні м. Вінниці видів роду Lonicera L. за особливими біоекологічними ознаками дало змогу виділити рослини, які мають високий декоративний ефект у різних типах насаджень. Введення їх у культуру сприяло естетичному оформленню приміських насаджень, поліпшенню санітарно-гігієнічного стану та дасть змогу розширити асортимент декоративних видів деревних рослин, який використовуєть для благоустрою населених місць (Kyryliuk, 2008).

Рід жимолость, котрий налічуе в собі близько 200 видів різного географічного походження, представлений в озелененні м. Вінниці переважно одним видом - Lonicera xylosteum L. Введення в культуру нових видів і форм потребує вивчення біологічних та екологічних особливостей рослин, визначення ступеня їх стійкості, визначення найбільш ефективних способів розмноження.

Аналіз останніх досліджень і публікацій. Широке й успішне використання жимолостей у культурі можливе на підставі всебічного вивчення біологічних, екологічних і народногосподарських особливостей цих рос- лин. Проблему інтродукції та поширення жимолостей в культурі вивчали такі науковці, як: Г. І. Музика, I. К. Гидзюк, З. Т. Артюшенко та ін.

Мета дослідження - провести аналіз процесів росту і розвитку найбільш поширених та перспективних видів роду Lonicera L. в м. Вінниці, порівняно з аборигенними видами, та обгрунтувати перспективність їх культивування в регіоні.

Результати дослідження та їх обговорення. Для порівняння ритму розвитку інтродуцентів у нових умовах ми взяли жимолость звичайну, як найбільш пристосовану до наших умов. Рослини, у яких вегетація або інша фаза розвитку починається або закінчується одночасно 3 місцевим видом, ми відносили до феногрупи середніх термінів. Рослини, які розпочинають вегетацію раніше або пізніше місцевого виду, - відповідно до ранньої або пізньої фенологічної групи (Kyryliuk, 2008). За термінами початку вегетації досліджувані жимолості ми відносили до феногрупи ранніх, а за термінами завершення - в групу зі середнім закінченням вегетації (табл. 1).

\section{Інформація про автора:}

Матусяк Михайло Васильович, канд. с.-г. наук, ст. викладач, кафедра садово-паркового господарства, садівництва та виноградарства. Email: mikhailo1988@gmail.com; https://orcid.org/0000-0001-8099-7290

цитування за ДСту: Матусяк М. В. Біолого-екологічні особливості використання видів роду жимолость (Lonicera L.) в умовах біостаціонару Вінницького національного аграрного університету. Науковий вісник НлтУ України. 2018, т. 28, № 10. С. 41-44.

Citation APA: Matusiak, M. V. (2018). Biologicaland ecological features of the use of representatives of Honeysuckle (Lonicera L.) Genus in the conditions of the biostationary of VNAU. Scientific Bulletin of UNFU, 28(10), 41-44. https://doi.org/10.15421/40281008 
Табл. 1. Тривалість вегетації жимолостей в умовах м. Вінниці

\begin{tabular}{|c|c|c|c|c|}
\hline Вид & $\begin{array}{c}\text { Розпускання } \\
\text { бруньок, } \\
\text { середні дати / } \\
\text { Сума позитив- } \\
\text { них темпера- } \\
\text { тур на цей пе- } \\
\text { ріод, }{ }^{\circ} \mathrm{C}\end{array}$ & $\begin{array}{c}\text { Масовий } \\
\text { листопад / Сума } \\
\text { ефективних тем- } \\
\text { ператур на цей } \\
\text { період, }{ }^{\circ} \mathrm{C}\end{array}$ & 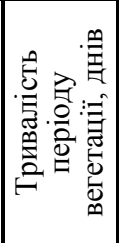 & 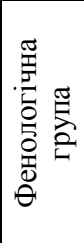 \\
\hline $\begin{array}{l}\text { Жимолость } \\
\text { каприфоль }\end{array}$ & $23.03-4.04 / 110$ & $11.10-26.10 / 1907$ & 227 & РП \\
\hline $\begin{array}{c}\text { Жимолость } \\
\text { звичайна }\end{array}$ & $4.04-16.04 / 157$ & $4.10-11.10 / 2036$ & 179 & $\mathrm{CC}$ \\
\hline
\end{tabular}

Ми встановили, що в наших умовах початок вегетації жимолостей розпочинається наприкінці березня - на початку квітня, коли середньодобова температура не перейшла через позначку $+5{ }^{\circ} \mathrm{C}$, тобто на початку загального вегетаційного періоду деревних рослин. Більшість досліджуваних видів починають вегетацію до 4.04, коли за середньо багаторічними даними починається період вегетації. Сума позитивних температур вище $0{ }^{\circ} \mathrm{C}$ в цей період становить від 32 до $216^{\circ} \mathrm{C}$. Пізніше цього терміну розпочинає вегетацію жимолость звичайна (рис. 1).

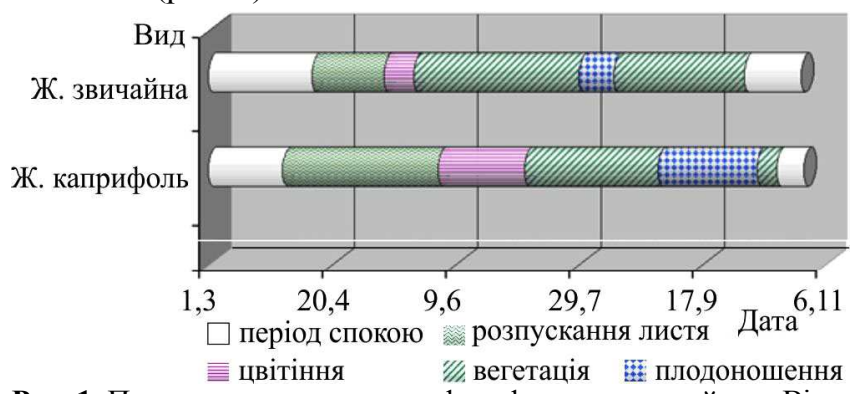

Рис. 1. Початок та проходження фенофаз жимолостей у м. Вінниці протягом 2017-2018 pp.

Різкі коливання температур, як правило, не завдають шкоди рослинам. Однак, у 2018 році після підняття температури вдень 3-5 січня до $+9-10^{\circ} \mathrm{C}$, погода різко змінилась і температура знизилась до - $15^{\circ} \mathrm{C}$. На рослинах жимолості звичайної і каприфолі було відзначено побуріння кінчиків пагонів. Повне облистнення у більшості видів відбувається у другій-третій декаді квітня.

За термінами закінчення вегетації досліджувані видами віднесли до феногрупи із середнім і пізнім термінами. До групи із середнім терміном закінчення вегетації ввійшла жимолость звичайна. Середні календарні терміни масового листопаду припадають на 4-11 жовтня. Середні календарні терміни у групи з пізнім закінченням вегетації припадають на 11-26 жовтня.

Отже, за термінами початку і закінчення вегетації виткі жимолості ми віднесли до двох феногруп: СС середнім початком і середнім закінченням вегетації (жимолость звичайна), РП - раннім початком та пізнім терміном закінчення вегетації (жимолості каприфоль) (Kokhno \& Kurdiuk, 1994).

Першою зі стану спокою виходить жимолость каприфоль, пізніше-жимолость звичайна. У жимолості каприфоль терміни завершення вегетації майже збігаються із термінами місцевих порід, або дещо виходять за межі вегетаційного періоду, внаслідок чого в деякі зими кінці їх однорічних пагонів пошкоджувались. Незважаючи на це, рослини цвіли і плодоносили. Середня тривалість вегетації досліджуваних видів становить близько 227 днів (рис. 2).

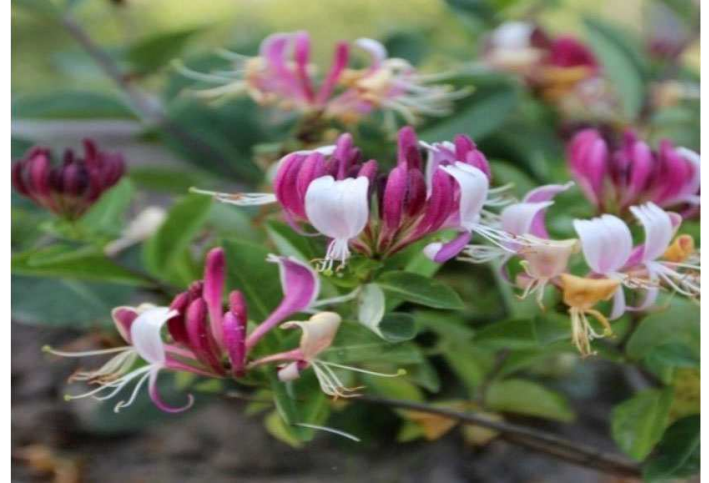

Рис. 2. Цвітіння жимолості каприфоль в умовах біостаціонару BHAY

Цінною біологічною особливістю жимолостей як кущових, так і витких, заради якої їх використовують в озелененні, є щорічне і рясне цвітіння. Наші досліди показали, що, залежності від метеорологічних явищ, кожного конкретного року терміни настання окремих фенофаз, зокрема цвітіння, можуть значно зсуватись, однак послідовність їх проходження зберігається (Lapyn \& Sydneva, 1973).

Середні терміни цвітіння досліджуваних видів жимолості наведено в табл. 2.

Табл. 2. Терміни цвітіння жимолостей у м. Вінниця

\begin{tabular}{|c|c|c|c|c|}
\hline \multirow{2}{*}{ Вид } & \multicolumn{2}{|c|}{$\begin{array}{c}\text { Середня дата } \\
\text { цвітіння } \\
\end{array}$} & \multirow{2}{*}{$\begin{array}{l}\text { Середня тривалість } \\
\text { періоду цвітіння, днів }\end{array}$} & \multirow{2}{*}{$\begin{array}{c}\text { Бал } \\
\text { цвітін- } \\
\text { ня }\end{array}$} \\
\hline & початок & $\begin{array}{l}\text { закін- } \\
\text { чення }\end{array}$ & & \\
\hline $\begin{array}{l}\text { Жимолость } \\
\text { звичайна }\end{array}$ & 15.05 & 28.05 & 13 & 5 \\
\hline $\begin{array}{l}\text { Жимолость } \\
\text { каприфоль }\end{array}$ & 3.06 & 10.07 & 36 & 5 \\
\hline
\end{tabular}

В умовах Вінниці цвітіння жимолостей в середньому триває від 13 до 36 днів. Також ми оцінювали плодоношення жимолостей в умовах біостаціонару ВНАУ. Період формування плодів у досліджуваних видів жимолості досить розтягнутий (від 96 до 132 днів) і залежить від суми накопичених температур, термінів цвітіння виду, його географічного походження та систематичного положення (табл. 3).

Табл. 3. Терміни дозрівання плодів жимолостей в умовах м. Вінниці

\begin{tabular}{|c|c|c|c|}
\hline \multirow[t]{2}{*}{ Вид } & \multicolumn{2}{|c|}{$\begin{array}{c}\text { Середня дата дос- } \\
\text { тигання плодів }\end{array}$} & \multirow{2}{*}{$\begin{array}{c}\text { Кількість днів від початку } \\
\text { цвітіння до масового } \\
\text { достигання плодів }\end{array}$} \\
\hline & початок & масове & \\
\hline $\begin{array}{c}\text { Жимолость } \\
\text { звичайна }\end{array}$ & 2.08 & 15.08 & 96 \\
\hline $\begin{array}{l}\text { Жимолость } \\
\text { каприфоль }\end{array}$ & 5.09 & 15.10 & 132 \\
\hline
\end{tabular}

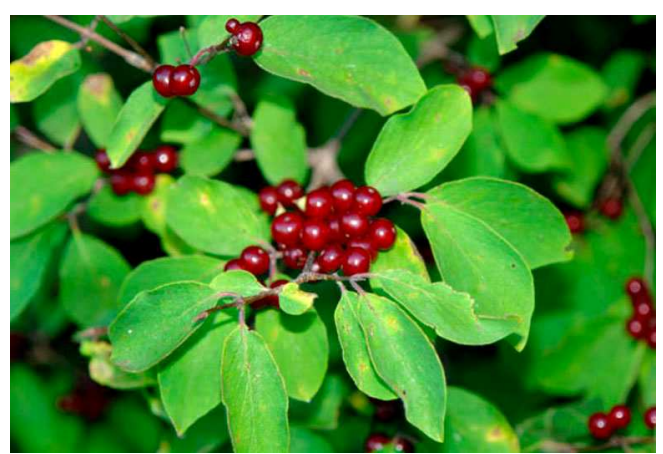

Рис. 3. Плодоношення жимолості звичайної (біостаціонар BHAY) 
Основним лімітуючим чинником для досліджуваних видів, які вивчають у Вінниці, $є$ низькі мінусові температури, а також уся система зовнішніх кліматичних умов, яких зазнають рослини під час зимівлі. Фактичну зимостійкість встановлювали за 5-бальною шкалою обмерзання М. К. Вєхова. Внаслідок проведених спостережень (табл. 4) виявлено пошкодження $40 \%$ верхівок однорічних пагонів жимолості каприфоль (до 1530 см), що однак не стало причиною втрати декоративності, оскільки цей вид має сильний приріст (60120 см), тож немає підстави стверджувати про цілковиту незимостійкість та малу перспективність цього виду. Жимолость звичайна обмерзання не мала. Завдяки нормальному розвитку пагонів, вид утворює добре сформовану крону, що $є$ для нього характерно (Muzyka, 2002).

Табл. 4. Вивчення зимостійкості польовим методом в умовах м. Вінниці (за М. К. Всховим)

\begin{tabular}{|c|c|c|c|}
\hline \multirow{2}{*}{ Вид } & \multicolumn{2}{|c|}{ Бал за роками } & \multirow{2}{*}{$\begin{array}{l}\text { Середнє } \\
\text { значення }\end{array}$} \\
\hline & 2017 & 2018 & \\
\hline $\begin{array}{c}\text { Жимолость } \\
\text { звичайна }\end{array}$ & 1 & 1 & 1 \\
\hline $\begin{array}{c}\text { Жимолость } \\
\text { каприфоль }\end{array}$ & 1 & 3 & 2,5 \\
\hline
\end{tabular}

Аналізуючи отримані результати, доходимо висновку, що найвищу фактичну зимостійкість в умовах м. Вінниці має вид жимолость звичайна.

Перспективність інтродукції досліджуваних жимолостей в наших умовах ми визначали методом інтегрального числового оцінювання на підставі візуальних спостережень та відобразили в табл. 5.

Табл. 5. Оцінка життсздатності та перспективності досліджуваних жимолостей у м. Вінниці, балів

\begin{tabular}{|c|c|c|c|c|c|c|c|c|c|c|}
\hline \multirow[b]{2}{*}{ Вид } & \multirow{2}{*}{ 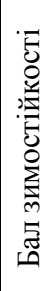 } & \multicolumn{7}{|c|}{$\begin{array}{c}\text { Показник життєздатності } \\
\text { та перспективності }\end{array}$} & \multicolumn{2}{|c|}{$\begin{array}{l}\text { Загаль- } \\
\text { на оцін- } \\
\text { ка }\end{array}$} \\
\hline & & 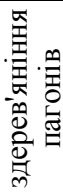 & 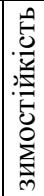 & 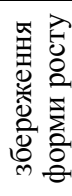 & 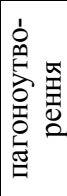 & 垈 & 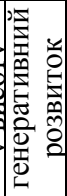 & 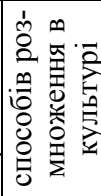 & 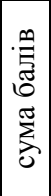 & 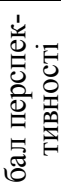 \\
\hline $\begin{array}{c}\text { Жимо- } \\
\text { лость кап- } \\
\text { рифоль }\end{array}$ & 2 & 15 & 20 & 10 & 5 & 5 & 25 & 7 & 89 & II \\
\hline $\begin{array}{c}\text { Жимо- } \\
\text { лость зви- } \\
\text { чайна }\end{array}$ & 1 & 20 & 25 & 10 & 3 & 5 & 25 & 7 & 96 & I \\
\hline
\end{tabular}

До групи перспективних ми віднесли середземноморський вид жимолость каприфоль. Рослини цієї гру- пи щорічно цвітуть і плодоносять, але дещо менш зимостійкі, ніж рослини першої групи.

Оскільки міські насадження виконують рекреаційні та захисні функції, вони потребують покращення видового складу та його збагачення, підвищення естетичної та санітарно-гігієнічної цінності. Варто зауважити, що міські насадження створюються переважно 3 аборигенних видів, однак сьогодні спостерігаємо тенденцію до заміни або доповнення їх інтродукованими видами, які добре адаптувались.

Висновки. Встановили, що тривалість цвітіння різних видів жимолості змінюється в межах від 13 до 36 днів, що дає змогу створювати декоративні насадження з різним періодом цвітіння. Період формування плодів у досліджуваних видів становить у межах 96132 днів. Під час вивчення зимостійкості досліджуваних видів жимолості встановлено, що найкраще пристосовується до негативних кліматичних умов жимолость звичайна. Вона витримує зниження температури до $-25^{\circ} \mathrm{C}$, при чому частка пошкоджених тканин становить до $25 \%$. Найгірше пристосовується до низьких температур жимолость каприфоль, що проявляється в обмерзанні однорічних пагонів. Однак це не стає причиною втрати декоративності, оскільки вид має сильний приріст.

Внаслідок вивчення життєздатності та перспективності досліджуваних видів жимолості встановлено, що цілком перспективними в умовах м. Вінниці виявились жимолость звичайна (бал перспективності - I), а жимолость каприфоль належить до групи перспективних видів (бал перспективності - II), що дає змогу широко використовувати ці види в озелененні міста.

\section{Перелік використаних джерел}

Kokhno, N. A. \& Kurdiuk, A. M. (1994). Theoretical foundations and experience of the introduction of woody plants in Ukraine. Kyiv: Naukova dumka, 186 p. [In Russian].

Kyryliuk, V. I. (2008). Morphobiological and ecological features types of Lonicera L. and perspectives their use in the field of s. Kiev. Abstract of Doctoral Dissertation for Biology Sciences (06.03.01 - Forest Crops and Phytomelioration). Kyiv. 24 p. [In Ukrainian].

Lapyn, P. Y. \& Sydneva, S. V. (1973). Evaluation of the prospects for the introduction of woody plants according to visual observations. Moscow: Publishing house. Hl. bot. sada AN SSSR. pp. 7-67.

Muzyka, H. I. (2002). Wickey honeysuckle. Uman: Umanskyi dendropark "Sofiivka", 144 p. [In Russian].

Riabova, N. V. (1980). Honeysuckle. Results of the introduction in Moscow. Moscow: Science. 160 p. [In Russian].

M. В. Матусяк

Винницкий национальный аграрный университет, Винница, Украина

\section{БИОЛОГО-ЭКОЛОГИЧЕСКИЕ ОСОБЕННОСТИ ИСПОЛЬЗОВАНИЯ ПРЕДСТАВИТЕЛЕЙ РОДА ЖИМОЛОСТЬ (LONICERA L.) В УСЛОВИЯХ БИОСТАЦИОНАРА ВНАУ}

Анализ результатов фенологических наблюдений проводился по 7 фазам, которые отражают основные моменты сезонного развития растений. Для сравнения ритма развития интродуцентов в новых условиях мы приняли жимолость обыкновенную, как наиболее приспособленную к нашим условиям. Мы установили, что в наших условиях начало вегетации жимолостей начинается в конце марта - начале апреля, когда среднесуточная температура не перешла через отметку $+6{ }^{\circ} \mathrm{C}$. Большинство исследуемых видов начинают вегетацию до 4.04, когда средне-многолетним данным начинается период вегетации у большинства растений. Позже этого срока начинает вегетацию жимолость обыкновенная. В результате наших исследований мы определили, что начало роста побегов в исследуемых видов наблюдается во второй-третьей декаде апреля. Этому соответствует средняя температура воздуха $6,8-10,5^{\circ} \mathrm{C}$, при сумме активных температур выше нуля $205-227^{\circ} \mathrm{C}$. Фактическую зимостойкость мы устанавливали по 5-балльной шкале обледенения Вехова М. К. В результате проведенных наблюдений выявлено повреждение 40 \% верхушек однолетних побегов жимолости каприфоль (до 15-30 см), что однако не стало причиной потери декоративности, поскольку данный вид имеет сильный прирост (60-120 см), поэтому нет основания утверждать о полной незимостийкости и малую перспективность данного вида. Жимолость обыкновенная обледенения не имела. 
Благодаря нормальному развитию побегов виды образуют хорошо сформированную крону, что для них характерно. Анализируя полученные результаты, приходим к выводу, что наиболее высокую фактическую зимостойкость в условиях г. Винницы имеет вид: жимолость обыкновенная. В результате изучения жизнеспособности и перспективности исследуемых видов жимолости установлено, что вполне перспективными в условиях биостационара ВНАУ оказались жимолость обыкновенная (балл перспективности - I), а жимолость каприфоль относится к группе перспективных видов (балл перспективности - II), что позволяет широко использовать данные виды в озеленении города.

Ключевые слова: биостационар; жимолость; адаптация; интродукция; акклиматизация; зимостойкость.

M. V. Matusiak

Vinnytsia National Agrarian University, Vinnytsia, Ukraine

\section{BIOLOGICAL AND ECOLOGICAL FEATURES OF THE USE OF REPRESENTATIVES OF HONEYSUCKLE (LONICERA L.) GENUS IN THE CONDITIONS OF THE BIOSTATIONARY OF VNAU}

The analysis of the results of phenological observations has been carried out by 7 phases, which reflect the main points of seasonal development of plants. To compare the rhythm of the development of introducers in the new conditions, we have used common honeysuckle as the most adapted to our conditions. We have found that in our conditions the growing of honeysuckle begins in late March - early April, when the average daily temperature does not exceed the mark of $+6{ }^{\circ} \mathrm{C}$. Most of the species under the study begin to vegetate at up to April 4, when, according to average long-term data, the vegetation period of most plants begins. After this period, the honeysuckle begins to grow normally. As a result of our research, we have determined that the beginning of growth of the studied species is observed in the second or third decade of April. The average air temperature of $6.8-10.5^{\circ} \mathrm{C}$ with the sum of active temperatures of $205-227^{\circ} \mathrm{C}$ above zero corresponds to this. We have established the actual winter hardiness by a 5-point scale of frosting by M.K. Vekhov. As a result of the observations, $40 \%$ of the heads of one-year honeysuckle shoots (up to 15-30 cm) have been found to be damaged, which, however, have not caused the loss of ornamentality, since this species has a strong regrowth $(60-120 \mathrm{~cm})$, so there is no reason to argue about the complete non-winter hardiness and low prospects of this species. Common honeysuckle usually does not get frosted. Due to the normal development of shoots, species form a well-formed crown that is their characteristic. Having analysed the results obtained, we have come to conclusion that common honeysuckle has the highest actual winter resistance in the conditions of Vinnytsia. As a result of the study of viability and prospects of the investigated species of honeysuckle, we have found that honeysuckle is quite promising under conditions of the Biostationary of VNAU (rate of prospectivity - I), while perfoliate honeysuckle belongs to a group of promising species (rate of prospectivity - II), which allows using these species for greening the towns.

Keywords: biostationary; honeysuckle; adaptation; introduction; acclimatization; winter hardiness. 